\title{
Structural and bioactive studies of terpenes and cyclopeptides from the Genus Rubia
}

\author{
Kuo Xu, Penglong Wang, Bin Yuan, Yatao Cheng, Qiang Li and Haimin Lei*
}

\begin{abstract}
Genus Rubia fell into about 70 species distributed widely around the world, a total of 36 species and 2 varieties were reported from China. The extracts and phytochemicals of Rubia plants had drawn considerable attention due to their potent bioactivities. As the two major ingredients from these plants, pentacyclic triterpenes and cyclopeptides were becoming a hot topic over the past twenty years for their remarkable anticancer, antioxidant and other effects. This paper compiled all 65 terpenes and 44 cyclopeptides with their distributions, physiological activities and melting points (or optical rotations) as reported in 85 references; besides, structure-activity relationships of these derivatives were briefly discussed. The information involved in this paper was expected to be meaningful for the further studies of the Genus Rubia.
\end{abstract}

Keywords: Genus Rubia, Phytochemicals, Terpenes, Cyclopeptides, Bioactivities

\section{Review}

\section{Introduction}

Genus Rubia that belongs to the Rubiaceae is one kind of perennial herbs; it falls into about 70 species distributed widely around the world, such as Western Europe, Northern Europe, Mediterranean Coast, Temperate Asia, Africa, Himalaya, as well as the regions from Mexico to Tropical America. A total of 36 species and 2 varieties have been reported from China [1]. Rubia species being one of the earliest plant resources possessed important commercial and medicinal values. Commercially, they were used as natural dye-stuffs in old days and improved commodity circulation; medically, these species being used as drugs were first recorded in the world famous pharmacy book of China, Divine Famer's Materia Medica, which has over 2000 years history [2]. According to many medical books, the roots of Rubia plants being reputed for their satisfactory efficacy were wildly used for the treatment of cancers, tuberculosis, rheumatism, hematemesis, metrorrhagia, epistaxis, contusion and menoxenia in the Chinese traditional medicine $[3,4]$. Besides, Indian folk medicine also comprised numerous prescriptions involved in Genus

\footnotetext{
* Correspondence: hm_lei@yahoo.cn

School of Chinese Pharmacy, Beijing University of Chinese Medicine, Beijing 100102, China
}

Rubia for healing wounds, inflammation, skin infections, and so on [5].

Within the last few decades, the extracts and phytochemicals of Rubia plants have drawn much attention due to their potent bioactivities. Studies on these plants led to the isolation of a series of bioactive ingredients including anthraquinones, naphthoquinones, terpenes, cyclopeptides and other constituents. Nine years ago, R. Singh etc. summarized a total of 33 terpenes and 19 cyclopeptides identified from 7 Rubia species [6]. Since then, researches on phytochemicals of Genus Rubia have achieved a lot and the lack of a comprehensive and lately review on this subject prompted us to gather much more new information. The previous review of us has introduced 148 anthraquinones and naphthoquinones together with their structure-activity relationships; herein we continue a general presentation of Rubia terpenes and cyclopeptides that exhibited remarkable anticancer, antioxidant and other effects. The present paper is dedicated to summarizing and updating a total of 65 terpenes and 44 cyclopeptides whose structures, distributions and properties are listed in the following tables and figures; furthermore, structure-activity relationships of these derivatives are briefly discussed. 


\section{Terpenes and their glycosides isolated from the Genus Rubia}

Terpenes were not generally considered as major effective ingredients existed in medicinal Rubia plants, but they were also the earliest phytochemicals isolated from Genus Rubia. To our knowledge, people have got 65 terpene derivatives including 5 monoterpenes and 60 pentacyclic triterpenes. Compared with the similar work in 2004, this paper supplemented 32 new terpenes; plant sources of several compounds were also extended. What's more, we modified some previous information; for instance, $\beta$-sitosterol, daucosterol and stigmasterol should be classified under the steroids rather than the terpenes; three pentacyclic triterpenes named 'Rubiprasins A-C' were mistaken as 'Rubiprassins A-C' and Rubiprasin C's structure was also wrongly described. All of the 65 terpenes and their glycosidic derivatives isolated from 8 Rubia species are listed in Table 1 together with melting points (or optical rotations); the structures of these compounds are described in Additional file 1: Figure S1.

\section{Monoterpenes}

Monoterpenes hold a relatively small proportion among Rubia terpenes. Up to 2012, researchers have identified 5 monoterpenes (1-5) distributed in 3 species including $R$. cordifolia, $R$. tinctorum and $R$. peregrina [7-9]; and it's just the continuous studies of the ethyl acetate fraction of $R$. cordifolia that resulted in the isolation of the monoterpenoid (5). More detailed information of monoterpenes is involved in the following Table and Figure.

\section{Pentacyclic triterpenes}

Most of Rubia pentacyclic triterpenes came from three species including $R$. schumanniana, R. peregrina, and $R$. yunnanensis, especially the latter. $R$. yunnanensis is known as "Xiao-Hong-Shen", which is endemic to China and has been served as an alternative for $R$. cordifolia; it has a long history of medicinal application in China. The aforementioned three Rubia species were rich sources for pentacyclic triterpenes. No report could be available on triterpene derivatives of Genus Rubia until 1981, when S. K. Talapatra etc. got Rubiacoumaric acid (6) and Rubiafolic acid (7) from $R$. cordifolia [10]. Several years after the discovery of the first two triterpenes, rubiprasins A-C and rubiarbonols A-F were identified from the same species $[11,12]$. The subsequent reported pentacyclic triterpenes were mainly designated under a series of names such as rubiarbonol, rubiarbonone, rubiarboside, rubiprasin and rubianol. It seemed that compounds named rubiarbonones, rubiarbosides, rubianols and rubianosides mainly existed in $R$. yunnanensis [13-22]. Friedelinol-type triterpene (63) that belonged to arborinane-type derivatives was previously isolated from the family Rubiaceae, but it's the first report for the isolation from the Genus Rubia [23]. Further phytochemical studies of Genus Rubia have resulted in identification of another 16 new triterpenes [24-37].

Except for compiling and summarizing the latest information, in the process of literature searching, we deem that some previous information is not credible. For instance, melting points of Rubiarbonone B (26) which roots in two different references should not be deviated too much $[14,16,18]$; it's also doubted that the structure of Rubiarboside F (34) was describe as IV's (49) [15,21]. More detailed information of Rubia triterpenes is listed in the following Table and Figure, Mp refers to Melting point; $[\alpha]$ means to the Specific Rotation of the compounds (due to different test conditions, the data may be various).

\section{Cyclopeptides isolated from the Genus Rubia}

Studies on plant cyclopeptides have drawn considerable attention for their distinctive bicyclic structural features and significant antitumor activities. On the basis of the chemical skeletons and distributions in plants, N. H. Tan etc. proposed the systematic structural classification of plant cyclopeptides which were divided into two classes, five subclasses, and eight types [38]. Followed by the rule, Rubia cyclopeptides should be classified under the Rubiaceae-type cyclopeptides formed with one $\alpha-\mathrm{D}$ alanine, one $\alpha$-L-alanine, three $N$-methyl- $\alpha$-L-tyrosines and one other proteinogenic $\alpha$-L-amino acid [39]. So far, people have got 44 cyclopeptide derivatives from the Genus Rubia. Compared with terpene derivatives, Rubia cyclopeptides have narrower sources and only existed in three species containing $R$. cordifolia, $R$. yunnanensis and $R$. akane. In general, according to these cyclopeptides' names, we may deduce their distributions; for instance, the cyclopeptides named Rubiyunnanins and RYs were reported from $R$. yunnanensis while the structures whose names were designated as RAs or others mainly came from $R$. cordifolia.

At the end of the twentieth century, cyclopeptides called RA-I (66) and RA-II (67) were isolated from chloroform and methanol extracts of $R$. cordifolia as the minor constituents [40]. It's the first time to report that Genus Rubia contained cyclopeptides. Later, RAs III-VII $(68,70-74)$ were obtained from the methanol extract of $R$. cordifolia together with $R$. akane [41-44]. As far as we know, among the reported cyclopeptides, only RA-V (71) and RA-VII (74) existed in R. akane. Except for aglycone, further studies on the Genus Rubia have also confirmed many cyclopeptide glycosides; these known glucosides were just single substituted glucopyranoside derivatives. For example, RA-XII (79), RA-XIII (80) and RA-XIV (81) were discovered in higher plants for the first time [45]; RA-XV (82) and RA-XVI (83) that 
Table 1 Structures of terpenes (1-65) and cyclopeptides (66-109) isolated from the Genus Rubia

\begin{tabular}{|c|c|c|c|}
\hline No. & Structures' name & $\mathrm{Mp} /{ }^{\circ} \mathrm{C}$ or $[a] /{ }^{\circ}$ & Resources \& References \\
\hline 1 & 6-methoxygeniposidic acid & - & R. cordifolia [7] \\
\hline \multirow[t]{2}{*}{2} & \multirow[t]{2}{*}{ Asperuloside } & $173-175[8]$ & R. tinctorum [8] \\
\hline & & 130-132 [33] & R. peregrina [9] \\
\hline 3 & Asperulosidic acid & {$[a]_{D}+21[33]$} & R. peregrina [9] \\
\hline 4 & Deacetylasperulosidic acid & {$[\mathrm{a}]_{\mathrm{D}}+21[33]$} & R. peregrina [9] \\
\hline 5 & $\begin{array}{l}\text { 3R,3aS,4R,6aR-3,4,6-tris (hydroxymethyl)-3,3a,4, } \\
\text { 6a-tetrahydro-2H-cyclopenta[b] furan-2-one }\end{array}$ & {$[a]_{D}^{22}+4[25]$} & R. cordifolia [25] \\
\hline 6 & Rubiacoumaric acid & $215 /[a]_{D}+24.5[10]$ & R. cordifolia [10] \\
\hline \multirow[t]{2}{*}{7} & \multirow[t]{2}{*}{ Rubiafolic acid } & \multirow[t]{2}{*}{$286-287 /[a]_{D}+58.8[10]$} & R. cordifolia [10] \\
\hline & & & R. schumanniana [20] \\
\hline 8 & Zamanic acid & {$[a]_{D}^{27}+26[35]$} & R. schumanniana [20] \\
\hline \multirow[t]{2}{*}{9} & \multirow[t]{2}{*}{ Maslinic acid } & \multirow[t]{2}{*}{$269-271[31]$} & R. schumanniana [20] \\
\hline & & & R. yunnanensis [22] \\
\hline 10 & Spathodic acid & $280[37]$ & R. yunnanensis [22] \\
\hline \multirow[t]{2}{*}{11} & \multirow[t]{2}{*}{ Ursolic acid } & \multirow[t]{2}{*}{$272-273[32]$} & R. schumanniana [20] \\
\hline & & & R. yunnanensis [22] \\
\hline \multirow[t]{3}{*}{12} & \multirow[t]{3}{*}{ Oleanolic acid } & 277.6-280.1 [31] & R. schumanniana [20] \\
\hline & & $281-282[32]$ & R. cordifolia [26] \\
\hline & & $280-282[34]$ & R. ustulata [27] \\
\hline 13 & Karachic acid & $260-261 /[a]_{D}+79[29]$ & R. schumanniana [20] \\
\hline 14 & 3-O-acetyloleanolic acid & $265-266[34]$ & R. ustulata [27] \\
\hline 15 & Oleanolic aldehyde acetate & $216-218[36]$ & R. cordifolia [7] \\
\hline \multirow[t]{3}{*}{16} & \multirow[t]{3}{*}{ Rubiarbonol A } & $260-263 /[a]_{D}+36.5[11]$ & R. cordifolia $[11,24]$ \\
\hline & & $260-262[13]$ & R. yunnanensis $[13,15,16,18,21,22]$ \\
\hline & & $289-290[16,18]$ & \\
\hline \multirow[t]{4}{*}{17} & \multirow[t]{4}{*}{ Rubiarbonol B } & \multirow[t]{4}{*}{$272-273 /[a]_{D}+30.3[11]$} & R. oncotricha [11] \\
\hline & & & R. yunnanensis [15] \\
\hline & & & R. cordifolia [24] \\
\hline & & & R. ustulata [27] \\
\hline 18 & Rubiarbonol C & $211-213 /[a]_{D}-4.3[11]$ & R. oncotricha [11] \\
\hline \multirow[t]{2}{*}{19} & \multirow[t]{2}{*}{ Rubiarbonol D } & \multirow[t]{2}{*}{$218-220 /[a]_{D}+6.1[11]$} & R. oncotricha [11] \\
\hline & & & R. akane [28] \\
\hline 20 & Rubiarbonol E & $290 /[a]_{D}+15.4[11]$ & R. oncotricha [11] \\
\hline \multirow[t]{3}{*}{21} & \multirow[t]{3}{*}{ Rubiarbonol F } & \multirow[t]{3}{*}{$280 /[a]_{D}+33.3[11]$} & R. oncotricha [11] \\
\hline & & & R. yunnanensis [15] \\
\hline & & & R. yunnanensis $[21,22]$ \\
\hline \multirow[t]{2}{*}{22} & Rubiarbonol G & $170-173[13]$ & R. yunnanensis $[13,15,16,18,22,30]$ \\
\hline & & $174-176[16,18]$ & \\
\hline 23 & Rubiarbonol K & - & R. schumanniana [20] \\
\hline & & & R. yunnanensis $[22,30]$ \\
\hline 24 & Rubiarbonol L & - & R. yunnanensis $[22,30]$ \\
\hline 25 & Rubiarbonone A & $153-155[13]$ & R. yunnanensis $[13,15,16,18,22,30]$ \\
\hline & & $160-162[16,18]$ & \\
\hline 26 & Rubiarbonone B & $155-157[14]$ & R. yunnanensis $[14-16,18,21,22]$ \\
\hline & & $255-256[16,18]$ & \\
\hline
\end{tabular}




\section{Table 1 Structures of terpenes (1-65) and cyclopeptides (66-109) isolated from the Genus Rubia (Continued)}

\begin{tabular}{|c|c|c|c|}
\hline 27 & Rubiarbonone C & $98-100[14]$ & R. yunnanensis $[14,21,22]$ \\
\hline 28 & Rubiarbonone D & $231-232 /[a]_{D}+94.4[15]$ & R. yunnanensis [15] \\
\hline 29 & Rubiarbonone $\mathrm{E}$ & $258-259 /[a]_{D}+233.4[15]$ & R. yunnanensis $[15,22]$ \\
\hline 30 & Rubiarbonone F & $253-254 /[a]_{D}+26.4[15]$ & R. yunnanensis [15] \\
\hline 31 & Rubiarboside A & - & R. yunnanensis $[15,21,22,30]$ \\
\hline 32 & Rubiarboside B & - & R. yunnanensis $[21,30]$ \\
\hline 33 & Rubiarboside C & - & R. yunnanensis $[21,22,30]$ \\
\hline 34 & Rubiarboside F & $294-295 /[a]_{D}+98.1[15]$ & R. yunnanensis [15] \\
\hline 35 & Rubiarboside G & $>290 /[a]_{D}+56.4[15]$ & R. yunnanensis $[15,22]$ \\
\hline \multirow[t]{3}{*}{36} & Rubiprasin A & $>300 /[a]_{D}+12.8[12]$ & R. cordifolia [12] \\
\hline & & & R. ustulata [27] \\
\hline & & & R. akane [28] \\
\hline \multirow[t]{3}{*}{37} & Rubiprasin B & $277-280[12]$ & R. cordifolia [12] \\
\hline & & & R. ustulata [27] \\
\hline & & & R. akane [28] \\
\hline 38 & Rubiprasin C & $171-173[12]$ & R. cordifolia [12] \\
\hline 39 & Rubiatriol & $252-256[17]$ & R. cordifolia [17] \\
\hline 40 & Rubianol-a & {$[a]_{D}^{25}+10.0[19]$} & R. yunnanensis $[19,21]$ \\
\hline 41 & Rubianol-b & {$[a]_{D}^{25}+16.8[19]$} & R. yunnanensis $[19,21]$ \\
\hline 42 & Rubianol-c & {$[a]_{D}^{25}+36.4[19]$} & R. yunnanensis $[19,21,22]$ \\
\hline 43 & Rubianol-d & {$[a]_{D}^{25}+63.6[19]$} & R. yunnanensis $[19,21,22]$ \\
\hline 44 & Rubianol-e & {$[a]_{D}^{25}+18.1[19]$} & R. yunnanensis $[19,21,22]$ \\
\hline 45 & Rubianol-g & {$[a]_{D}^{25}+206.1[21]$} & R. yunnanensis [21] \\
\hline 46 & Rubianoside I & {$[a]_{D}^{25}+10.9[19]$} & R. yunnanensis $[19,21,22]$ \\
\hline 47 & Rubianoside ॥ & {$[a]_{D}^{25}+2.2[21]$} & R. yunnanensis [21] \\
\hline 48 & Rubianoside III & {$[a]_{D}^{25}+3.5[21]$} & R. yunnanensis [21] \\
\hline 49 & Rubianoside IV & {$[a]_{D}^{25}+90.5[21]$} & R. yunnanensis [21] \\
\hline 50 & $3 \beta, 6 a-d i h y d r o x y-u r s-14-e n-12-o n e$ & {$[a]_{D}^{20}-10.7[20]$} & R. schumanniana [20] \\
\hline 51 & 3ß-hydroxy-urs-30-p-Z-hydroxycinnamoyl-12-en-28-oic-acid & {$[a]_{D}^{16}+6.5[20]$} & R. schumanniana [20] \\
\hline 52 & 3ß-hydroxy-olean-30-p-E-hydroxycinnamoyl-12-en-28-oic-acid & {$[a]_{D}^{16}+13.1[20]$} & R. schumanniana [20] \\
\hline 53 & Rubiarbonol A 7-acetate & {$[a]_{D}^{23}+1.7[22]$} & R. yunnanensis [22] \\
\hline 54 & Rubiyunnanol A & {$[a]_{D}^{16}+23.2[22]$} & R. yunnanensis [22] \\
\hline 55 & Rubiyunnanol B & $247-248 /[a]_{D}^{16}+25.8[22]$ & R. yunnanensis [22] \\
\hline 56 & 19,28-Didehydroxyrubiarbonol A & {$[a]_{D}^{16}+39.7[22]$} & R. yunnanensis [22] \\
\hline 57 & Rubiyunnanol C & {$[a]_{D}^{18}-28.9[22]$} & R. yunnanensis [22] \\
\hline 58 & Rubiarbonone E 19-acetate & $259-260 /[a]_{D}^{23}-4.6[22]$ & R. yunnanensis [22] \\
\hline 59 & 2-Hydroxyrubiarbonone E & {$[a]_{D}^{23}+19.7[22]$} & R. yunnanensis [22] \\
\hline 60 & Rubianol-e3-O-(6'-O-acetyl)- $\beta$-D-Gluc & {$[a]_{D}^{25}-25.2[22]$} & R. yunnanensis [22] \\
\hline 61 & 2a-Acetoxy-28-acetylrubiarboside G & {$[a]_{D}^{16}-27.9[22]$} & R. yunnanensis [22] \\
\hline 62 & Rubiarboside G 28-acetate & {$[a]_{D}^{16}-21.7[22]$} & R. yunnanensis [22] \\
\hline 63 & 3- $\beta$-friedelinol & $281-283[23]$ & R. cordifolia [23] \\
\hline 64 & Rubiarboside G 28-al & {$[a]_{D}^{16}-41.7[22]$} & R. yunnanensis [22] \\
\hline 65 & Rubiarbonol A 3-O- $\beta$-D-glucopyranosyl- (1-2)- $\beta$-D-Gluc & {$[a]_{D}^{16}-9.0-9.0[22]$} & R. yunnanensis [22] \\
\hline
\end{tabular}


belonged to glucosides were identified from $R$. cordifolia [46]; in addition, J. T. Fan etc. reported that Rubiyunnanins B (93), F (97), G (98), H (99), and RYs I-III (100-102) also contained glycosyl [47-58]. Beyond that mentioned skeleton, uncommonly, chloroform-soluble portion of methanol extracts from the roots of $R$. cordifolia gave a dimer named RA-dimer A (103), in which two molecules of deoxybouvardin were linked together via an ether linkage [59]; however, it's a pity for us that chemical constructions of RA-700 and RC-18 haven't been available $[60,61]$. Just in last year, Y. Hitotsuyanagi etc. got a series of special cyclopeptides from the Genus Rubia [62,63].

The complete list of cyclopeptides isolated from 3 Rubia species is summarized in Table 2 together with the physical properties; their structures are described in Additional file 2: Figure $\mathrm{S} 2$; herein $\mathrm{Mp}$ refers to Melting point, $[\alpha]$ means to the Specific Rotation (due to different test conditions, the data may be various), $\beta$-D-Gluc refers to $\beta$-D-glucopyranoside.

\section{Biological activities of Rubia terpenes and Rubia cyclopeptides}

Various crude fractions and purified compounds from the Genus Rubia exhibited a relatively wide range of biological activities [64-69]. Numerous experimental data verified that pentacyclic triterpenes possessed potent advantage on the aspects of antitumor, antiinflammatory, protecting liver, anti-HIV effects [70], while the most significant advantage of plant cyclopeptides was their underlying mechanisms of antitumor effects. As the two major ingredients existed in those Rubia plants, pentacyclic triterpenes and cyclopeptides were becoming a hot topic over the past twenty years for their remarkable effects. The following contents aims to offer the detailed statements of pharmacological activities of Rubia terpenes and cyclopeptides, especially their anticancer and antioxidant effects. Finally, all the bioactive terpenes and cyclopeptides together with the sketchy mechanisms are collected in Table 3.

\section{Anticancer effects of Rubia terpenes and Rubia cyclopeptides \\ Cytotoxicity and inhibitory on cell lines}

Rubiarbonols A (16) and F (21), rubiarbonone C (27), and rubianol-c (42) exhibited cytotoxic effects in the MTT assay and they could also inhibit NO production [19]. Compounds 7-9, 11-13, 23 and 50-52 had been evaluated for cytotoxicity against three human cancer cell lines including Hela, BGC-823 and A549; then compounds $8-9,11,50$ and 52 showed cytotoxicity with the $\mathrm{IC}_{50}$ values of $10.75 \sim 18.87 \mu \mathrm{g} / \mathrm{ml}$ [20]. Compounds $22,54,55,58$ and 62 had inhibition on A549, Hela and SMMC-7721; however, the data were not very satisfactory [22]. Rubiarbonol A (16) was reported to have relatively strong cytotoxicity against HT-29; compared rubiarbonols $\mathrm{A}$ and $\mathrm{B}$, introduction of the hydroxyl group on C-28 seemed to enhance cytotoxicity, especially on HT-29. Besides, compound 15 exhibited potent bioactivities against A549, SK-OV-3, SK-MEL-2, MES-SA and HCT-15 [36].

Different from pentacyclic triterpenes' wide bioactivities, the effects of Rubia cyclopeptides mainly focused on inhibitory against tumors; and it's available to identify bioactive cyclopeptides. An efficient isolation method for antitumor cyclopeptides from Genus Rubia had been established by following the activity against murine tumor P388 leukemia that was successfully used to purify RAs I-IV (66-70) [40]. In a similar way, $\mathrm{H}$. Itokawa etc. [41] found that the methanolic extract prepared from roots of $R$. cordifolia had a significant antitumor activity against Sarcoma 180 ascites and P388 leukemia in mice, from which RAs-III, -IV, -V (71) and -VII (74) were obtained. Recent years, monoclonal antibodies against RA-VII (74) had been also generated for screening of antitumor cyclopeptides. T. Hasuda etc. proved that they were useful for checking of the RA series compounds in the roots of $R$. cordifolia and R. akane [71].

Various data exhibited that different structural residues of Rubia cyclopeptides seemed to be closely related with their anticancer effects. Studies on the effect of RA-XVII (84) on cytotoxicity and conformation showed that although the structure exhibited little effect on the conformation of the molecule, it might decrease the activity as the side chain of residue 1 grew longer [47]. On the basis of several cyclopeptide derivatives, the typical type II $\beta$-turn structure and the aromatic side chain of Tyr-3 over this turn were also considered to play a very important role in its antitumor activities [42]. RA-X (77) containing a glutamic acid at residue 2 possessed strong antitumour effect on P388 while RA-IX (76) with conformation restricted to a type II $\beta$-turn at residues 2 and 3 showed almost no antitumour activities [43]. RAs XI-XIV (78-81) had potent antitumor activity against P388, especially the compound 79 whose residue 2 was methyl. The conformation of cis $\mathrm{N}$-methyl amide bond between residues 2 and 3 also played an important role in the antitumour activities of RAs [50]. RA-XVIII (85) was another natural peptide of the RA-series in which the benzene ring of Tyr- 6 was hydroxylated and its cytotoxicity against P-388 was $0.012 \mu \mathrm{g} / \mathrm{ml}$ [51]. RA-XIX, -XX, -XXI and -XXII (86-89) had been evaluated for their cytotoxicity against P388, with RA-VII (74) as reference; for the compounds having a methoxyl group in Tyr-6, the order of cytotoxicity was $74>87>86$. Compound 89 possessing a hydroxyl group in its Thr-2 was less cytotoxic than 88 . It seemed that the cytotoxicity decreased with increased in the length of the carbon side chain or introduction of a polar functionality at this 
Table 2 Structures of terpenes (1-65) and cyclopeptides (66-109) isolated from the Genus Rubia

\begin{tabular}{|c|c|c|c|}
\hline NO. & Derivatives' names & $\mathrm{Mp} /{ }^{\circ} \mathrm{C}$ or $[\mathrm{a}] /^{\circ}$ & Distributions \& References \\
\hline \multirow[t]{2}{*}{66} & RA-I & $284[40]$ & R. cordifolia [40] \\
\hline & & & R. yunnanensis [55] \\
\hline 67 & RA-II & $261[40]$ & R. cordifolia [40] \\
\hline 68 & RA-III & $>300[40] /[a]_{D}^{28}-199[41]$ & R. cordifolia $[40,41,44]$ \\
\hline 69 & RAI-III & $209-211 /[a]_{D}-38.3[48]$ & R. cordifolia [48] \\
\hline 70 & RA-IV & $247-255[40] /[a]_{D}^{28}-126[41]$ & R. cordifolia $[40,41,44]$ \\
\hline \multirow[t]{3}{*}{71} & RA-V & $>300 /[a]_{D}^{21}-225[41]$ & R. cordifolia $[41,44]$ \\
\hline & & & R. akane [41] \\
\hline & & & R. yunnanensis $[55,56]$ \\
\hline 72 & RA-VI & $219-220 /[a]_{D}-118.6[42]$ & R. cordifolia [42] \\
\hline 73 & RAI-VI & $200-202 /[a]_{D}-129.4[48]$ & R. cordifolia [48] \\
\hline \multirow[t]{2}{*}{74} & RA-VII & $>300 /[a]_{D}^{21}-229[41]$ & R. cordifolia $[41,44,50]$ \\
\hline & & & R. akane [41] \\
\hline 75 & RA-VIII & $267-269 /[a]_{D}-159.5[42]$ & R. cordifolia [42] \\
\hline 76 & RA-IX & $242-243 /[a]_{D}^{20}-158.1[43]$ & R. cordifolia [43] \\
\hline 77 & RA-X & $254.5-255.5 /[a]_{D}^{20}-205.4[43]$ & R. cordifolia [43] \\
\hline 78 & RA-XI & $255.5 /[a]_{D}-235.8[45]$ & R. cordifolia [45] \\
\hline \multirow[t]{2}{*}{79} & RA-XII & $252-255 /[a]_{D}-270.0[45]$ & R. cordifolia $[45,49]$ \\
\hline & & & R. yunnanensis $[21,55]$ \\
\hline 80 & RA-XIII & $273-276 /[a]_{D}-109.3[45]$ & R. cordifolia [45] \\
\hline 81 & RA-XIV & $264-267 /[a]_{D}-257.8[45]$ & R. cordifolia [45] \\
\hline 82 & $\mathrm{RA}-\mathrm{XV}$ & $218-220 /[a]_{D}-202.4[46]$ & R. cordifolia [46] \\
\hline 83 & $\mathrm{RA}-\mathrm{XVI}$ & $220 /[a]_{D}-179.7[46]$ & R. cordifolia [46] \\
\hline 84 & $\mathrm{RA}-\mathrm{XVII}$ & {$[a]_{D}^{24}-194[47]$} & R. cordifolia [47] \\
\hline 85 & RA- XVIII & {$[a]_{D}^{25}-222[51]$} & R. cordifolia [51] \\
\hline 86 & RA- XIX & {$[a]_{D}^{26}-224.4[52]$} & R. cordifolia [52] \\
\hline 87 & $R A-X X$ & {$[a]_{D}^{26}-218.4[52]$} & R. cordifolia [52] \\
\hline 88 & RA- XXI & $>300 /[a]_{D}^{26}-230.1[52]$ & R. cordifolia [52] \\
\hline 89 & RA- XXII & {$[a]_{D}^{26}-186.7[52]$} & R. cordifolia [52] \\
\hline 90 & RA- XXIII & $254-256 /[a]_{D}^{26}-184.2[53]$ & R. cordifolia [53] \\
\hline \multirow[t]{2}{*}{91} & RA- XXIV & $258-261 /[a]_{D}^{26}-168.5[53]$ & R. cordifolia $[53,63]$ \\
\hline & & & R. yunnanensis [55] \\
\hline 92 & Rubiyunnanin A & {$[a]_{D}^{28}-115.8[54]$} & R. yunnanensis [54] \\
\hline 93 & Rubiyunnanin B & {$[a]_{D}^{24}-205.8[54]$} & R. yunnanensis [54] \\
\hline 94 & Rubiyunnanin C & $253-254 /[a]_{D}^{27}-221.0[55]$ & R. yunnanensis [55] \\
\hline 95 & Rubiyunnanin D & {$[a]_{D}^{23}-149.7[55]$} & R. yunnanensis [55] \\
\hline 96 & Rubiyunnanin E & {$[a]_{D}^{23}-124.5[55]$} & R. yunnanensis [55] \\
\hline 97 & Rubiyunnanin F & {$[a]_{D}^{25}-182.5[55]$} & R. yunnanensis [55] \\
\hline 98 & Rubiyunnanin G & {$[a]_{D}^{28}-127.3[55]$} & R. yunnanensis [55] \\
\hline 99 & Rubiyunnanin $\mathrm{H}$ & {$[a]_{D}^{27}-244.0[55]$} & R. yunnanensis [55] \\
\hline 100 & RY-I & $226-228 /[a]_{D}^{25}-267[56]$ & R. yunnanensis [56] \\
\hline 101 & RY-II & - & R. yunnanensis $[55,57]$ \\
\hline 102 & RY-III & - & R. yunnanensis $[6,58]$ \\
\hline 103 & RA-dimer A & {$[a]_{D}^{25}-247[59]$} & R. cordifolia [59] \\
\hline
\end{tabular}


Table 2 Structures of terpenes (1-65) and cyclopeptides (66-109) isolated from the Genus Rubia (Continued)

\begin{tabular}{llll}
\hline 104 & RA-700 & - & R. cordifolia [6,60] \\
105 & RC-18 & - & R. cordifolia $[6,61]$ \\
106 & Allo-RA-V & {$[\mathrm{a}]_{\mathrm{D}}^{25}-234[62]$} & R. cordifolia $[62]$ \\
107 & Neo-RA-V & {$[\mathrm{a}]_{\mathrm{D}}^{25}-290[62]$} & R. cordifolia $[62]$ \\
108 & O-seco-RA-V & {$[\mathrm{a}]_{\mathrm{D}}^{25}-82[62]$} & R. cordifolia [62] \\
109 & O-seco-RA-XXIV & {$[\mathrm{a}]_{\mathrm{D}}^{25}-62[63]$} & R. cordifolia $[63]$ \\
\hline
\end{tabular}

location [52]. RA-XXIII (90) and RA-XXIV (91) exhibited just moderate cytotoxicity against P-388 with $\mathrm{IC}_{50}$ values of 0.16 and $0.48 \mathrm{mg} / \mathrm{ml}$, respectively [53]. T. Koizumi etc. had ever applied RA-VII (74) for the treatment of tumors in mice; daily intraperitoneal injection of RA-VII (1.5 or $3 \mathrm{mg} / \mathrm{kg} /$ day) had no toxic effects on those animals, but significantly and dose dependently inhibited the growth of Lewis lung carcinoma cells previously inoculated into the mice [72].

Compared with the various sources and remarkable effects of RAs, cyclopeptides named after Rubiyunnanin only existed in $R$. yunnanensis and their efficacies on tumors were relatively weaker. Cytotoxicities of Rubiyunnanin A (92) and B (93) against the 11 cancer cell lines were measured by SRB assay, but only 93 possessed moderate cytotoxicities [54]. Rubiyunnanins C-H (94-99) and RA-V, RA-I, RA-XXIV, RA-XII, RY-II not only exhibited cytotoxicities against the same cell lines with $\mathrm{IC}_{50}$ values ranging from 0.001 to $56.24 \mu \mathrm{M}$, but also exerted inhibitions against NO production in LPS and IFN-c-induced RAW 264.7 murine macrophages with $\mathrm{IC}_{50}$ values ranging from 0.05 to $12.68 \mu \mathrm{M}$ [55]. RYs I-III (100-102), RA-700 (104), and RC-18 (105) possessed only medium activities against P388 [56-58,60,61]. The newly identified compounds 106-108, and RA-V, VII were evaluated for their cytotoxic activities against
HL-60 and HCT-116 while only the latter had potent cytotoxicities [62]. Moreover, compound 109 exhibited cytotoxic effects on HL-60 cells, but which was much weaker than those of RA-XXIV and RA-VII [63].

\section{Inducing cell apoptosis}

Researchers paid much attention on anticancer mechanisms of maslinic acid (9), ursolic acid (11) and oleanolic acid (12) over the past decade years. No obvious correlation could be observed between cytotoxicity and inhibitory activity of DNA relaxation and decatenation by DNA topoisomerases I and II [24]. Oleanolic acid had selective inhibitory activity against DNA topoisomerase II compared with DNA topoisomerase I but weak cytotoxicity against HT-29, MCF-7 and HepG2 [26]. Maslinic acid was able to induce caspase-dependent apoptosis in human coloncancer cells via the intrinsic mitochondrial pathway [73,74]; it could also potentiate anti-tumor activities of TNF- $\alpha$ and inhibit pancreatic tumor growth and invasion by activating caspase-dependent apoptotic pathway and by suppressing NF- $\mathrm{kB}$ activation and its downstream gene expression [75]. Inhibition of Protein kinase $\mathrm{C}$ (PKC) that was related to the tumor development might lead to inhibition of cells growth and spreading of cancer cells, while maslinic acid acted as a PKC inhibitor. Ursolic acid potentiated TRAIL-induced apoptosis through activation of reactive oxygen species and

Table 3 The biological activities of terpenes and cyclopeptides from the Genus Rubia

\begin{tabular}{|c|c|c|c|}
\hline Parts & Biological activities & Mechanisms of action & Compounds' code names \\
\hline \multirow[t]{3}{*}{4.1} & Anticancer effect & Cytotoxicity and inhibitory on cell lines & $\begin{array}{l}8,9,11,15,16,21,22,27,42,50,52,54,55,58 \\
62,66-71,74,77-81,84-102,104,105,109\end{array}$ \\
\hline & & Inducing cell apoptosis. & $9,11,12$ \\
\hline & & Antiangiogenic & 71,74 \\
\hline 4.2 & Antioxidant effect & NO production & $16,21,27,42,43,44,66,71,79,91,93-99,101$ \\
\hline \multirow[t]{5}{*}{4.3} & Other effects & Antiplatelet aggregation & $16,17,25$ \\
\hline & & Antimicrobial & $11,12,22$ \\
\hline & & Antiobesity & 11,12 \\
\hline & & Antidiabetic & $9,11,12$ \\
\hline & & Anti-HIV & 9,11 \\
\hline
\end{tabular}


JNK-mediated up-regulation of death receptors and downregulation of decoy receptor 2 and cell survival proteins [76,77]; it was also considered as a novel blocker of STAT3 activation that might have a potential in prevention and treatment of multiple myeloma and other cancers [78]. Ursolic acid and oleanolic acid possessed markedly apoptotic effects on four cell lines via increasing DNA fragmentation, decreasing mitochondrial membrane potential, lowering $\mathrm{Na}^{+}-\mathrm{K}^{+}$-ATPase activity and elevating caspase- 3 and caspase- 8 activities; they could suppress cell adhesion and reduce the production of VEGF and ICAM-1 in these cell lines [79].

\section{Antiangiogenic effect}

Compared with the inhibition of Rubia cyclopeptides on cell lines, antiangiogenic effect of them were rarely involved. Sato and his coworkers demonstrated the antiangiogenic activity of RA-VII (74) on the proliferation, migration, stress fiber formation of BAEC and effects on mouse corneal angiogenesis [72]. Last year, G. G. L. Yue etc. discovered RA-V (71) also possessed the activity in HUVEC and HMEC-1 with changes in function of these endothelial cells. The underlying mechanisms of action involved the ERK1/2 signalling pathway; however, RA-V might regulate different signalling pathways in various endothelial cells [80].

\section{Antioxidant effects of Rubia terpenes and Rubia cyclopeptides}

Free radical NO was reported to be implicated in lots of physiological and pathological processes including vasodilation, nonspecific host defense and chronic or acute inflammation. It was produced by the oxidation of L-arginine under NO synthase (NOS). In the family of NOS, iNOS was particularly involved in pathological aspects with overproduction of $\mathrm{NO}$, which could be expressed in response to pro-inflammatory agents such as interleukin- $1 \beta$, tumor necrosis factor-a and lipopolysaccharide (LPS) in various cell types such as macrophages, endothelial cells and smooth muscle cells [21].

The bioactivities of rubianols on NO production from LPS-activated macrophages had been examined. Rubianol-d (43) and rubianol-e (44) exhibited the inhibition without cytotoxicity in the MTT assay whose efficacy was equivalent to L-NMMA's; rubianol-c (42), rubiarbonols A (16) and F (21), rubiarbonone C (27) showed both cytotoxic and inhibitory activities on NO production [19]. RA-V (71) and RA-XII (79) were demonstrated to possess potent effects on iNOS induction, and the suppression was closely related to their inhibitions of NO [21]. Inhibitory effects of Rubiyunnanin A-H (92-99) and RA-V, RA-I, RA-XXIV, RA-XII, RY-I were also evaluated; all of the compounds except 92 exhibited activity against NO production in LPS [54].

\section{Other effects of Rubia triterpenes \\ Antiplatelet aggregation effect}

Among compounds 16, 17 and 25, Rubiarbonol B (17) exhibited the most potent inhibition against arachidonic acid-induced and collagen-induced platelet aggregation at $150 \mu \mathrm{M}$, while Rubiarbonol A (16) and Rubiarbonone A (25) promoted platelet aggregation at the high doses and possessed antiplatelet aggregation activity at the lower concentrations. This result might be consistent with a basic tenet of Traditional Chinese Medicine, in that variations of the dose of prescriptions induced either stimulatory or inhibitory effects [15].

\section{Antimicrobial effects}

Antibacterial activity against Staphylococcus aureus and antifungal activity against Candida albicans of triterpenes from $R$. yunnanensis were evaluated using the turbidimetric method; compound 22 exhibited inhibition on both of the two strains [22]. Besides, ursolic acid (11) and oleanolic acid (12) possessed fairly high antimicrobial activities but were weaker than clinical antimicrobial drugs'; however, both of them exhibited low toxicity and might be used for treatment of infections by Vancomycin-Resistant Enterococci [81].

\section{Antiobesity effect}

Excess visceral adiposity might predispose to chronic diseases like hypertension and type-II diabetes with a high risk for coronary artery disease. Adipose tissue secreted cytokines and oxidative stress played an important role in the chronic disease progression. Triterpene derivatives had abilities to regulate glucose and lipid metabolism. C. L. Melo etc. [31] verified that oleanolic acid (12) could ameliorate visceral adiposity and improve glucose tolerance in mice and had an antiobesity potential through modulation of carbohydrate and fat metabolism. Much attention was also focused on food that might be beneficial in preventing diet-induced body fat accumulation and possibly reducing the risk of diabetes and heart disease; then ursolic acid (11) was demonstrated to have potent bioactivities improving certain metabolic parameters associated with diets high in saturated fats and obesity [82].

\section{Antidiabetic effect}

As a natural and low toxic compound, maslinic acid (9) elicited excellent outcomes without inducing the side effects. It exhibited significant glucose-lowering and hypoinsulinemic effects in $\mathrm{KK}-\mathrm{A}^{\mathrm{y}}$ mice and might hold great promise as a natural therapeutic agent for treatment of type-II diabetes [83]. Furthermore, both ursolic acid (11) and oleanolic acid (12) markedly 
suppressed renal aldose reductase activity and enhanced the activity of glyoxalase I, which contributed to decrease renal AGEs formation and improve renal functions; therefore, supplement of oleanolic acid and ursolic acid or foods rich in these compounds might be helpful for the prevention or treatment of diabetic kidney diseases [84].

\section{Anti-HIV effect}

Two triterpenes, maslinic acid (9) and ursolic acid (11), were reported to possess inhibition on the human immunodeficiency virus (HIV-1) protease [85].

\section{Conclusions}

To our knowledge, the reported Rubia terpenes distributed in 8 species and most of them derived from $R$. yunnanensis. The triterpenes were designated under a series of names including rubiarbonol, rubiarbonone, rubiarboside, rubiprasin and rubianol; among them, oleanane-type and fernane-type triterpenes accounted for overwhelming majority. Rubia cyclopeptides had narrower sources and existed in only 3 species including $R$. cordifolia, $R$. yunnanensis and $R$. akane. These terpenes and cyclopeptides, especially the latter, possessed excellent anticancer effects; maslinic acid, ursolic acid, oleanolic acid and several cyclopeptides containing RA-V and RA-VII drew relatively more attention than any other compound. From Table 3 and Additional file 1: Figure S1, it may be inferred that the Rubia triterpenes owning a free hydroxyl group on third carbon atom exhibited relatively strong inhibitory on cell lines; besides, fernane-type triterpenes possessed promising antioxidant effects. As for Rubia cyclopeptides, increase in the length of carbon side chain at residues 1,2 and introduction of polar groups at residue 2 might decrease structure's cytotoxicity; N-methyl amide bond between residues 2 and 3, together with aromatic side chain of residue 3 over $\beta$-turn played pivotal role in the antitumor activities. Beyond that, the orientation of one or both of the Tyr-5 and Tyr- 6 phenyl rings was also essential to express activities, while structures possessing two rings formed between Tyr- 5 and residue 6 via a phenolic oxygen linkage and a new carbon bond only possessed moderate cytotoxicities.

Up to now, phytochemical investigations of the Genus Rubia have resulted in identification of various chemical components including anthraquinones, naphthoquinones, terpenes and cyclopeptides. This paper dedicated to compiling all 65 terpenes derivatives and 44 cyclopeptides derivatives from 8 Rubia species. Together with the previous work, we have already finished summarizing a total of 257 compounds from 12 Rubia species with their bioactivities. However, taking into account the fact that 70 species belong to the Genus Rubia spreading around the world, only $17 \%$ of them have been phytochemically investigated, the Genus Rubia still remains to be a potential resource to research. Furthermore, as one kind of natural dyestuffs, resource exploration of Genus Rubia is also an asset to economic development and waits for its full exploitation.

\section{Additional files}

Additional file 1: Figure S1. Chemical structures of Rubia terpenes 1-65.

Additional file 2: Figure S2. Chemical structures of Rubia

cyclopeptides 66-109.

Competing interests

The authors declare that they have no competing interests.

\section{Authors' contributions}

KX, PW, HL have all been involved in drafting this review. BY, YC, and QL read and approved the final manuscript. All authors read and approved the final manuscript.

\section{Acknowledgments}

This part of work is partially supported by the National Natural Science Foundation of China (No.81073017; No. 81173519), and the Innovation Team Project Foundation of Beijing University of Chinese Medicine named 'Lead Compounds Discovering and Developing Innovation Team Project Foundation' (No. 2011-CXTD-15).

Received: 28 December 2012 Accepted: 11 April 2013

Published: 4 May 2013

\section{References}

1. Chen WQ, Luo XR, Gao YZ, Ruan YZ: Flora of China: Rubiaceae. Beijing 1999, 71(1):287-318.

2. Xu K, Wang PL, Wang L, Liu CM, Xu SX, Cheng YT, Wang YH, Li Q, Lei HM: Quinone derivatives from Genus Rubia plants and their bioactivities. Chem Biodivers. doi:10.1002/cbdv.201200173. in press.

3. Zhao SM, Kuang B, Fan JT, Yan H, Xu WY, Tan NH: Antitumor cyclic hexapeptides from Rubia plants: history, chemistry, and mechanism (2005-2011). CHIMIA Int J Chem 2011, 65(12):952-956.

4. Chinese Pharmacopoeia Commission: Chinese Pharmacopoeia. Part I. Beijing; 2010:218-219.

5. Meena AK, Pal B, Panda P, Sannd R, Rao MM: A review on Rubia cordifolia: its phyto constituents and therapeutic uses. Drug Invention Today 2010, 2(5):244-246.

6. RamSingh G, Chauhan SMS: 9, 10-anthraquinones and other biologically active compounds from the Genus Rubia. Chem Biodivers 2004, 1(9):1241-1242.

7. Wu U, Wang SX, Hua HM, Li X, Zhu TR, Miyase T, Ueno A: 6-methoxygeniposidic acid, an iridoid glycoside from Rubia cordifolia. Phytochemistry 1991, 30(5):1710-1711.

8. El-Emary NA, Backheet EY: Three hydroxymethylanthraquinone glycosides from Rubia tinctorum. Phytochemistry 1998, 49(1):277-279.

9. Ozgen U, Kazaz C, Secen H, Calis I, Coskun M, Houghton PJ: A novel naphthoquinone glycoside from Rubia peregrina L. Turk J Chem 2009, 33:561-568.

10. Talapatra SK, Sarkar AC, Talapatra B: Two pentacyclic triterpenes from Rubia cordifolia. Phytochemistry 1981, 20(8):1923-1927.

11. Itokawa H, Qiao YF, Takeya K: New arborane type triterpenoids from Rubia cordifolia var. pratensis and R. oncotricha. Chem Pharm Bull 1990, 38(5):1435-1437.

12. Itokawa H, Qiao YF, Takeya K, litaka Y: New triterpenoids from Rubia cordifolia var. pratensis (Rubiaceae). Chem Pharm Bull 1989, 37(6):1670-1672

13. Zou C, Hao XJ, Chen CX, Zhou J: New arborane type triterpenoids from Rubia yunnanensis (I). Acta Botanica Yunnanica 1993, 15(1):89-91.

14. Zou C, Hao XJ, Chen CX, Zhou J: Structures of Rubiarbonone B and C. Acta Botanica Yunnanica 1999, 21(2):256-259.

15. Liou MJ, Wu TS: Triterpenoids from Rubia yunnanensis. J Nat Prod 2002, 65(9):1283-1287. 
16. Xu XY, Zhou JY, Fang QC: Chemical constituents of Rubia yunnanensis root. J Chin Pharmaceut Sci 1995, 4(3):157-160.

17. Arisawa M, Ueno H, Nimura M, Hayashi T, Morita N: Rubiatriol, a new triterpenoid from the Chinese Drug Qián Cáo Gén. Rubia cordifolia. J Nat Prod 1986, 49(6):1114-1116

18. Xu XY, Zhou JY, Fang QC: Study on the chemical constituents of Rubia Yunnanensis Diels. Acta Pharmaceutica Sinica 1994, 29(3):237-240.

19. Morikawa T, Tao J, Ando S, Matsuda H, Yoshikawa M: Absolute stereostructures of new arborinane-type triterpenoids and inhibitors of nitric oxide production from Rubia yunnanensis. J Nat Prod 2003, 66(5):638-645.

20. Kuang B, Han J, Zeng GZ, Chen XQ, He WJ, Tan NH: Three new triterpenoids from Rubia schumanniana. Nat Prod Bioprospect 2012, 2:166-169.

21. Tao J, Morikawa T, Ando S, Matsuda H, Yoshikawa M: Bioactive constituents from Chinese natural medicines. XI. ${ }^{1)}$ Inhibitors on NO production and degranulation in RBL-2H3 from Rubia yunnanensis: structures of Rubianosides II, III, and IV, Rubianol-g, and Rubianthraquinone. Chem Pharm Bull 2003, 51(6):654-662.

22. Fan JT, Kuang B, Zeng GZ, Zhao SM, Ji CJ, Zhang YM, Tan NH: Biologically active arborinane-type triterpenoids and anthraquinones from Rubia yunnanensis. J Nat Prod 2011, 74(10):2069-2080.

23. Ibraheim ZZ, Gouda YG: Minor constituents from Rubia Cordifolia L. root. Bull Pharm Sci 2010, 33(2):225-233.

24. Son JK, Jung JH, Lee CS, Moon DC, Choi SW, Min BS, Woo MH: DNA Topoisomerases I and II inhibition and cytotoxicity of constituents from the roots of Rubia cordifolia. Bull Korean Chem Soc 2006, 27(8):1231-1234.

25. Jeong SY, Zhao BT, Lee CS, Son JK, Min BS, Woo MH: Constituents with DNA Topoisomerases I and II inhibitory activity and cytotoxicity from the roots of Rubia cordifolia. Planta Med 2012, 78(2):177-181.

26. Son JK, Jung SJ, Jung JH, Fang Z, Lee CS, Seo CS, Moon DC, Min BS, Kim MR, Woo MH: Anticancer constituents from the roots of Rubia cordifolia L. Chem Pharm Bull 2008, 56(2):213-216

27. Liou MJ, Teng CM, Wu TS: Constituents from Rubia ustulata Diels and R. yunnanensis Diels and their Antiplatelet Aggregation Activity. J Chin Chem Soc 2002, 49(6):1025-1030.

28. Chung MI, Jou SJ, Cheng TH, Lin CN, Ko FN, Teng CM: Antiplatelet constituents of formosan Rubia akane. J Nat Prod 1994, 57(2):313-316.

29. Khan MA, Rahman A: Karachic acid: A new triterpenoid from Betula utilis. Phytochemistry 1975, 14(3):789-791.

30. Zou C, Hao XJ, Chen CX, Zhou J: A new antitumor glycocyclohexapeptide and arborane type new triterpenoids Rubia yunnanensis. Acta Botanica Yunnanica 1992, 14(1):114

31. Melo CL, Queiroz MGR, Fonseca SGC, Bizerra AMC, Lemos TLG, Melo TS, Santos FA, Rao VS: Oleanolic acid, a natural triterpenoid improves blood glucose tolerance in normal mice and ameliorates visceral obesity in mice fed a high-fat diet. Chem-Biol Interact 2010, 185(1):59-65.

32. Chen $L S, L V Y, X u S W, X i n Y$ : Study on the triterpene acids in fruit of Crataegus pinnatifida. Lishizhen Med Mater Med Res 2008, 19(12):2909-2910.

33. Peng JN, Feng XZ, Li GY, Liang XT: Chemical investigation of Genus Hedyotis II. Isolation and identification of iridoids from Hedyotis Chrysotricha. Acta Pharmaceutica Sinica 1997, 32(12):908-913.

34. Xie RR, Guo J, Zhang DZ, Yan CY: Study on chemical constituents of compound ZhenzhuTiaozhi. Journal of Guangdong Pharmaceutical College 2010, 26(4):332-333.

35. Siddiqui BS, Firdous, Begum S: Two triterpenoids from the leaves of Plumeria obtuse. Phytochemistry 1999, 52(6):1111-1115.

36. Kim MR, Lee HH, Hahm KS, Moon YH, Woo ER: Pentacyclic triterpenoids and their cytotoxicity from the stem bark of Styraxjaponica S. et Z. Arch Pharm Res 2004, 27(3):283-286.

37. Ngouela S, Nyasse B, Tsamo E, Sondengam BL, Connollya JD: Spathodic acid: a triterpene acid from the stem bark of Spathodea campanulata. Phytochemistry 1990, 29(12):3959-3961.

38. Tan NH, Zhou J: Plant cyclopeptides. Chem Rev 2006, 106(3):840-895

39. Zhao SM, Kuang B, Fan JT, Yan H, Xu WY, Tan NH: Antitumor cyclic hexapeptides from Rubia Plants: History, Chemistry, and Mechanism (2005-2011). CHIMIA 2011, 65(12):952-956.

40. Itokawa H, Takeya K, Mori N, Sonobe T, Mihashi S, Hamanaka T: Studies on Antitumor cyclic hexapeptides RA obtained from Rubiae Radix Rubiaceae. Vl: minor antitumor constituents. Chem Pharm Bull 1986, 34(9):3762-3768.
41. Itokawa H, Takeya K, Mihara K, Mori N, Hamanaka T, Sonobe T, litaka Y: Studies on the antitumor cyclic hexapeptides obtained from Rubiae Radix. Chem Pharm Bull 1983, 31(4):1424-1427

42. Itokawa $\mathrm{H}$, Morita $\mathrm{H}$, Takeya $\mathrm{K}$, Tomioka N, Itai A, litaka Y: New antitumor bicyclic hexapeptides, RA-VI and -VIII from Rubia cordifolia; conformation-activity relationship II. Tetrahedron 1991, 47(34):7007-7020.

43. Itokawa H, Yamamiya T, Morita H, Takeya K: New antitumour bicyclic hexapeptides, RA-IX and-X from Rubia cordifolia. Part 3.

Conformation-antitumour activity relationship. J Chem Soc, Perkin Trans 1 1992, 4:455-459.

44. Itokawa H, Takeya K, Mori N, Hamanaka T, Sonobe T, Mihara K: Isolation and antitumor activity of cyclic hexapeptides isolated from Rubiae Radix. Chem Pharm Bull 1984, 32(1):284-290.

45. Morita H, Yamamiya T, Takeya K, Itokawa H: New antitumor bicyclic hexapeptides, RA-XI, -XII, -XIII and -XIV from Rubia cordifolia. Chem Pharm Bull 1992, 40(5):1352-1354.

46. Takeya K, Yamamiya T, Morita H, Itokawa H: Two antitumour bicyclic hexapeptides from Rubia cordifolia. Phytochemistry 1993, 33(3):613-615

47. Hitotsuyanagi $Y$, Ishikawa $H$, Hasuda $T$, Takeya $K$ : Isolation, structural elucidation, and synthesis of RA-XVII, a novel bicyclic hexapeptide from Rubia cordifolia, and the effect of side chain at residue 1 upon the conformation and cytotoxic activity. Tetrahedron Lett 2004, 45(5):935-938.

48. Itokawa H, Morita H, Takeya K, Tomioka N, Itai A: RAI-III and VI, conformational isomers of antitumor cyclic hexapeptides, RA-III and VI from Rubia cordifolia. Chemistry Lett 1991, 20(12):2217-2220.

49. Morita H, Yamamiya T, Takeya K, Itokawa H, Sakuma C, Yamada J, Suga T: Conformational recognition of RA-XII by 80 S Ribosomes: a differential line broadening study in ${ }^{1} \mathrm{H}$ NMR spectroscopy. Chem Pharm Bull 1993, 41(4):781-783

50. Itokawa $\mathrm{H}$, Morita $\mathrm{H}$, Kondo $\mathrm{K}$, Hitotsuyanagi $Y$, Takeya $\mathrm{K}$, litaka $\mathrm{Y}$ : Isomerization of antitumour bicyclic hexapeptide, RA-VII from Rubia cordifolia. Part 4. conformation- antitumour activity relationship. J Chem Soc, Perkin Trans 2 1992, 9:1635-1642.

51. Lee JE, Hitotsuyanagi Y, Kim IH, Hasuda T, Takeya K: A novel bicyclic hexapeptide, RA-XVIII, from Rubia cordifolia: structure, semi-synthesis, and cytotoxicity. Bioorg Med Chem Lett 2008, 18(2):808-811.

52. Lee JE, Hitotsuyanagi $Y$, Takeya K: Structures of cytotoxic bicyclic hexapeptides, RA-XIX, -XX, -XXI, and -XXII, from Rubia cordifolia L. Tetrahedron 2008, 64(18):4117-4125.

53. Lee JE, Hitotsuyanagi Y, Fukaya H, Kondo K, Takeya K: New cytotoxic bicyclic hexapeptides, RA-XXIII and RA-XXIV, from Rubia cordifolia L. Chem Pharm Bull 2008, 56(5):730-733.

54. Fan JT, Chen YS, Xu WY, Du LC, Zeng GZ, Zhang YM, Su J, Li Y, Tan NH: Rubiyunnanins $A$ and $B$, two novel cyclic hexapeptides from Rubia yunnanensis. Tetrahedron Lett 2010, 51(52):6810-6813.

55. Fan JT, Su J, Peng YM, Li Y, Li J, Zhou YB, Zeng GZ, Yan H, Tan NH: Rubiyunnanins $\mathrm{C}-\mathrm{H}$, cytotoxic cyclic hexapeptides from Rubia yunnanensis inhibiting nitric oxide production and NF-KB activation. Bioorg Med Chem 2010, 18(23):8226-8234.

56. Zou C, Hao XJ, Zhou J: Antitumor glycocyclohexapeptide from Rubia yunnanensis. Acta Botanica Yunnanica 1993, 15(4):399-402.

57. He M, Zou C, Hao XJ, Zhou J: A new antitumor cyclic hexapeptide glycoside from Rubia yunnanensis. Acta Botanica Yunnanica 1993, 15(4):408.

58. He M, Zou C, Hao XJ, Zhou J: New antitumor glycocyclohexapeptide from Rubia yunnanensis. Chinese Chem Lett 1993, 4:1065.

59. Hitotsuyanagi Y, Aihara T, Takeya K: RA-dimer A, a novel dimeric antitumor bicyclic hexapeptide from Rubia cordifolia L. Tetrahedron Lett 2000, 41(32):6127-6130.

60. Hamanaka T, Ohgoshi M, Kawahara K, Yamakawa K, Tsuruo T, Tsukagoshi S: A novel antitumor cyclic hexapeptide (RA-700) obtained from Rubiae radix. Pharmaceutical Society of Japan 1987, 10(11):616-623.

61. Adwankar MK, Chitnis MP: In vivo anti-Cancer activity of RC-18. Chemotherapy 1982, 28(4):291-293.

62. Hitotsuyanagi $Y$, Odagiri M, Kato S, Kusano Jl, Hasuda T, Fukaya H, Takeya K: Isolation, structure determination, and synthesis of Allo-RA-V and Neo-RA-V, RA-Series bicyclic peptides from Rubia cordifolia L. Chem Eur J 2012, 18(10):2839-2846.

63. Hitotsuyanagi $Y$, Kusano II, Kim IH, Hasuda T, Fukaya H, Takeya K: O-Seco-RA-XXIV, a possible precursor of an antitumor peptide RA-XXIV, from Rubia cordifolia L. Phytochem Lett 2012, 5(2):335-339. 
64. Krishnaiah VC, Ishaq BM, Kumar CH, Kumar JGS: Antidiarrhoeal activity of root extracts of Rubia cordifolia Linn. JGTPS 2011, 2(4):476-488.

65. Patel PR, Raval BP, Karanth HA, Patel VR: Potent antitumor activity of Rubia cordifolia. International Journal of Phytomedicine 2011, 2(1):44-46.

66. Joharapurkar AA, Zambad SP, Wanjari MM, Umathe SN: In vivo evaluation of antioxidant activity of alcoholic extract of Rubia cordifolia Linn. and its influence on ethanol-induced immunosuppression. Indian J Pharmacol 2003, 35(4):232-236.

67. Baskar R, Bhakshu LM, Bharathi GV, Reddy SS, Karuna R, Reddy GK, Saralakumari D: Antihyperglycemic activity of aqueous root extract of Rubia cordifolia in streptozotocin- induced diabetic rats. Pharm Biol 2006, 44(6):475-479.

68. Charde RM, Charde MS, Fulzele SV, Satturwar PM, Joshi SB: Wound healing activity of ethanolic extract of Rubia Cordifolia roots. J Pharm Res 2010, 3(12):3070-3071.

69. Deoda RS, Kumar D, Bhujbal SS: Gastroprotective effect of Rubia cordifolia Linn. on aspirin plus pylorus-ligated ulcer. Evid base Compl Alternative Med 2011, 2011(Article ID 541624):5. doi:10.1155/2011/541624. http://www. hindawi.com/journals/ecam/2011/541624/abs/.

70. Cheng $\mathrm{XH}$, Xiong YQ: Advances in studies on pharmacological activities of pentacyclic triterpenoid saponins. Chinese Traditional and Herbal Drugs 2007, 38(5):792-795.

71. Hasuda T, Hitotsuyanagi Y, Takeya K: Production of monoclonal antibodies against antitumor cyclohexapeptide RA-VII from Rubia cordifolia and their characterization. J Nat Med 2011, 65(3):588-593.

72. Koizumi T, Abe M, Yamakuni T, Ohizumi Y, Hitotsuyanagi Y, Takeya K, Sato Y: Metronomic scheduling of a cyclic hexapeptide Ra-VII for anti-angiogenesis, tumor vessel maturation and anti-tumor activity. Cancer Sci 2006, 97(7):665-674.

73. Reyes-Zurita FJ, Rufino-Palomares EE, Lupianez JA, Cascante: Maslinic acid, a natural triterpene from Olea europaea L., induces apoptosis in HT29 human colon-cancer cells via the mitochondrial apoptotic pathway. Cancer Lett 2009, 273(1):44-54.

74. Juan ME, Planas JM, RuizGutierrez V, Daniel H, Wenzel U: Antiproliferative and apoptosis inducing effects of maslinic and oleanolic acids, two pentacyclic triterpenes from olives, on HT29 colon cancer cells. Brit J Nutr 2008, 100(1):36-43.

75. Li CH, Yang ZF, Zhai CY, Qiu WW, Li DL, Yi ZF, Wang L, Tang J, Qian M, Luo J, Liu MY: Maslinic acid potentiates the anti-tumor activity of tumor necrosis factor a by inhibiting NF-KB signaling pathway. Mol Cancer 2010, 9:73-85.

76. Mooi LY, Yew WT, Hsum YW, Soo KK, Hoon LS, Chieng YC: Suppressive effect of maslinic acid on PMA-induced Protein Kinase $C$ in Human B-Lymphoblastoid Cells. Asian Pac J Cancer P 2012, 13:1177-1182.

77. Prasad S, Yadav VR, Kannappan R, Aggarwal BB: Ursolic Acid, a pentacyclic triterpene, potentiates TRAIL-induced apoptosis through p53-independent up-regulation of death receptors. J Biol Chem 2011, 286(7):5546-5557.

78. Pathak AK, Bhutani M, Nair AS, Ahn KS, Chakraborty A, Kadara H, Guha S, Sethi G, Aggarwal BB: Ursolic acid inhibits STAT3 activation pathway leading to suppression of proliferation and chemosensitization of human multiple myeloma cells. Mol Cancer Res 2007, 5(9):943-955.

79. Yan SL, Huang CY, Wu ST, Yin MC: Oleanolic acid and ursolic acid induce apoptosis in four human liver cancer cell lines. Toxicol in Vitro 2010, 24(3):842-848

80. Yue GGL, Fan JT, Lee JKM, Zeng GZ, Ho TWF, Fung KP, Leung PC, Tan NH, Lau CBS: Cyclopeptide RA-V inhibits angiogenesis by down-regulating ERK1/2 phosphorylation in HUVEC and HMEC-1 endothelial cells. Brit J Pharmacol 2011, 164(7):1883-1898.

81. Horiuchi K, Shiota S, Hatano T, Yoshida T, Kuroda T, Tsuchiya T: Antimicrobial activity of oleanolic acid from Salvia officinalis and related compounds on Vancomycin-Resistant Enterococci (VRE). Biol Pharm Bull 2007, 30(6):1147-1149.

82. Jayaprakasam B, Olson LK, Schutzki RE, Tai MH, Nair MG: Amelioration of obesity and glucose intolerance in High-Fat-Fed C57BL/6 mice by anthocyanins and ursolic acid in Cornelian Cherry (Cornus mas). $J$ Agric Food Chem 2006, 54(1):243-248.
83. Liu J, Sun HB, Duan WG, Mu DY, Zhang LY: Maslinic acid reduces blood glucose in KK-Ay mice. Biol Pharm Bull 2007, 30(11):2075-2078.

84. Wang ZH, Hsu CC, Huang CN, Yin MC: Anti-glycative effects of oleanolic acid and ursolic acid in kidney of diabetic mice. Eur J Pharmacol 2010, 628(1-3):255-260.

85. Xu HX, Zeng FQ, Wan M, Sim KY: Anti-HIV triterpene acids from Geum japonicum. J Nat Prod 1996, 59(7):643-645.

doi:10.1186/1752-153X-7-81

Cite this article as: Xu et al.: Structural and bioactive studies of terpenes and cyclopeptides from the Genus Rubia. Chemistry Central Journal 2013 $7: 81$

Publish with ChemistryCentral and every
scientist can read your work free of charge
"Open access provides opportunities to our
colleagues in other parts of the globe, by allowing
anyone to view the content free of charge."
W. Jeffery Hurst, The Hershey Company.
- available free of charge to the entire scientific community
- peer reviewed and published immediately upon acceptance
- cited in PubMed and archived on PubMed Central
- yours - you keep the copyright
submit your manuscript here:
http://www.chemistrycentral.com/manuscript/

